http:/www.vtu.lt/english/cditions

2003. Vol IX, No 1, 10-15

\title{
CONTACT LOSS BETWEEN RAILWAY TRACK AND SUBGRADE IN VERTICAL PLANE DURING ROADBED RESEARCH
}

\author{
Wlodzimierz Bednarek ${ }^{1}$, Alfredas Laurinavičius ${ }^{2}$ \\ ${ }^{1}$ Division of Railway Construction, Institute of Civil Engineering, Faculty of Civil and Environmental \\ Engineering and Architecture, Poznań University of Technology, ul. Piotrowo 5, \\ 61-138 Poznań, Poland. E-mail: bednarek@sol.put.poznan.pl \\ ${ }^{2}$ Dept of Roads, Vilnius Gediminas Technical University, Sauletekio al. 11, LT-2040 Vilnius, \\ Lithuania.E-mail: alfla@ap.vtu.lt
}

Received 09 Oct 2001; accepted 21 Nov 2002

\begin{abstract}
In the paper a new method of railway subgrade investigation is analysed. Contact loss between track and subgrade in vertical plane is considered. During the roadbed investigations the rail is jacked up using a plate called "VSS". It is assumed that variable temperatures have influence on the rail which is laid on a curved roadbed. Elasticity of the railway roadbed is calculated. Finally formulas and dependences of various types of track structures are obtained.
\end{abstract}

Keywords: railway, roadbed, flexibility, curve radius, influence of temperature.

\section{Introduction}

Since 1994 modernisation of E-20 line is being done in Poland. Geotechnical investigation of subgrade is based mainly on measuring modulus of elasticity (beyond standard geotechnical research - exploratory bore-holes, sounding, laboratory studies) [1-3]. This method, when VSS plate with equipment is used, gives the occasion to static pressure on layer of roadbed. Usually a plate of $30 \mathrm{~cm}$ diameter is used.

Before railway line reconstruction geotechnical research of roadbed was carried out. During the research the problem of measurement of elasticity modulus arose. As the trains pass the rail track, it is impossible to use optional counterbalance. That's why mainly the weight of track is used to carry out measurements. The scheme of the first way of research is shown in Fig 1.

There are some doubts about this method (first of all a very heavy supporting rail (4) - difficult transporting and fitting, no direct support of the rail (arose offcentre) and rail movement - (changing state of track). Because of that brand a new method of measurement was created [4].

\section{Research using the new method}

The new method is applied using a channel bar fastened to the ends of neighbouring sleepers. It results in reducing the movement of track (supported directly above the tested point) and deviation from the centre (Fig 2).
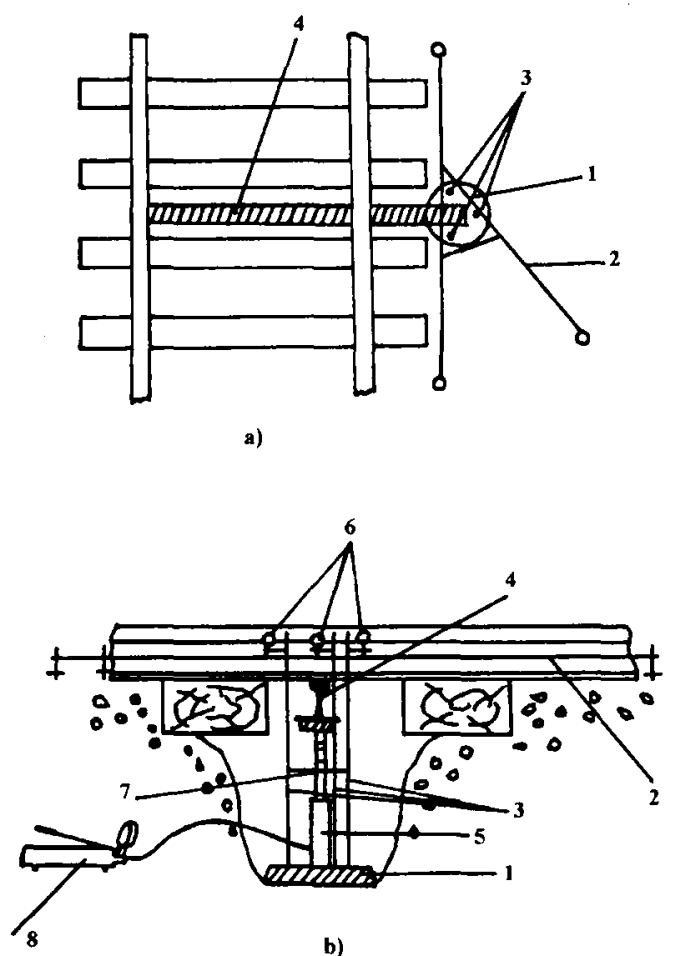

Fig 1. Equipment used during the first measurement: a) plan, b) profile. 1 - stiff plate, 2 - tripod, 3 - steel bars to fasten gauges, 4 - supporting rail, 5 - hydraulic lift, 6 - gauges, 7 - stiffing ring, 8 - hydraulic pump 

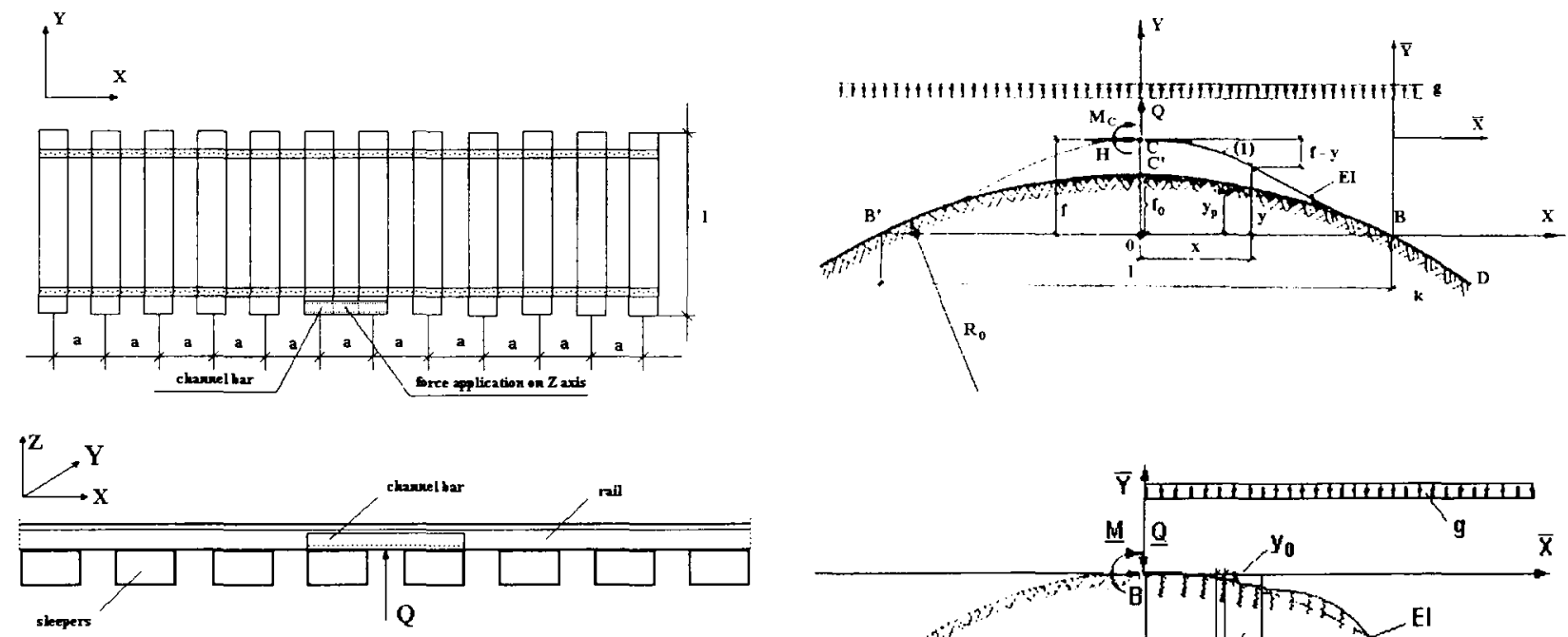

Fig 2. Diagram of the investigated section: a) horizontal view; b) longitudinal section

\section{Contact loss between railway track and subgrade in vertical plane}

\subsection{Model description}

In this model track is regarded as a clamped beam. In the analysis, lateral applied force, preliminary curve and flexibility of subgrade are considered. It is assumed that:

1) subgrade is flexible;

2) beam length modification is neglected;

3 ) only half of external force $(Q)$ affects the beam (symmetric configuration);

4) influence of shear force $(T)$ on system of internal active force is neglected.

Computed track is loaded by a continuous load $g$ (weight of track) and concentrated force $Q$ (repair machines or testing equipment).

The following configuration is calculated [5]:

- track as a heavy beam (weight, g);

- bending stiffness in vertical plane EI;

- compression by lateral force $\mathrm{H}$;

- the track is laid on the curved Winkler's roadbed (with radius $R_{0}$ ) with railway ballast at roadbed coefficient (k) per length segment of the track.

The track is lifted by external force (Q) (for example, during research of roadbed) on length (l) (Fig 3) [5].

Because of the system symmetry, only the right side of the beam CBD is considered [6].

\subsection{Static and mathematical analysis}

For the interval CB (bar without roadbed contact, Fig 3) we obtained a differential equation:

$$
E I \cdot \frac{d^{2} y}{d x^{2}}=M_{C}+H \cdot(f-y)+\frac{Q}{2} \cdot x-\frac{g \cdot x^{2}}{2} .
$$

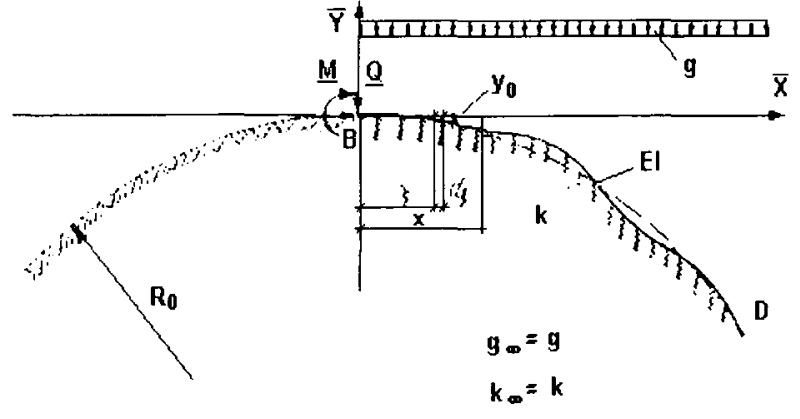

Fig 3. Computed model

For interval BD (bar with roadbed contact, in Fig 3) we have obtained:

$$
d^{4} y x^{4}-\frac{H}{E I} \cdot d d^{2} y+\frac{k}{E I} \cdot y(x)=\frac{k}{E I} \cdot y_{P}+\frac{g}{E I}
$$

where a slightly curved roadbed deflection is given as a function:

$$
y_{0}=\frac{x^{2}}{2 \cdot R_{0}},
$$

where $R_{0}$ - radius of a curved Winkler's roadbed.

Finally, the equation of deformed beam for interval $\mathrm{CB}$ is:

$$
\frac{d^{4} y}{d x^{4}}=-\frac{H}{E I} \cdot \frac{d^{2} y}{d x^{2}}-\frac{g}{E I} .
$$

After substitution:

$$
\beta^{2}=\stackrel{H}{E \cdot I} .
$$

Final solution of the calculated equation (4) is:

$$
y=A \cdot \sin \beta x+B \cdot \cos \beta x+C+D \cdot x-\frac{g \cdot x^{2}}{2 \cdot H} .
$$

Four unknowns A, B, C and D we obtain from the following boundary conditions:

$$
\begin{gathered}
x=0 ; \begin{array}{l}
d y \\
d x
\end{array}=0, \\
x=0, E I \cdot \frac{d^{3} y}{d x^{3}}=T(0)=\frac{Q}{2}
\end{gathered} .
$$


Considering the above dependences we obtain: from the first condition

$$
A=-\frac{Q}{2 \cdot H \cdot \beta}
$$

from the second condition

$$
D=\frac{Q}{2 \cdot H}
$$

Finally we obtain the following form of equation (without the unknowns $\mathrm{B}$ and $\mathrm{C}$ ):

$$
\begin{gathered}
y=-\frac{Q}{2 \cdot H \cdot \beta} \sin \beta x+B \cdot \cos \beta x+C+\frac{Q}{2 \cdot H} \cdot x-\frac{g \cdot x^{2}}{2 \cdot H} \\
-\frac{g \cdot x^{2}}{2 \cdot H} .
\end{gathered}
$$

Doing similar assumptions for the interval BD (2) we obtain a solution in local coordinate system:

$$
\begin{gathered}
y=e^{-\overline{\varphi_{1}} \bar{x}} \cdot\left(\bar{A} \cdot \sin \left(\overline{\varphi_{2} x}\right)+\bar{B} \cdot \cos \left(\overline{\varphi_{2}} \bar{x}\right)\right)+e^{\overline{\varphi_{1}} \bar{x}} . \\
\left(\bar{C} \cdot \sin \left(\overline{\varphi_{2}} \bar{x}\right)+\bar{D} \cdot \cos \left(\overline{\varphi_{2} x}\right)\right)-\frac{\overline{x^{2}}}{2 \cdot R_{0}}-\frac{g}{k},
\end{gathered}
$$

where

$$
\varphi_{1}=\sqrt{\frac{1}{2} \sqrt{\frac{k}{E I}}-\frac{H}{4 \cdot E I}} ; \varphi_{2}=\sqrt{\frac{1}{2} \cdot \sqrt{\frac{k}{E I}}+\frac{H}{4 \cdot E I}} .
$$

We have four unknowns $\ddot{A}, B, C$ and $\bar{D}$ from the following boundary conditions:

$$
\begin{gathered}
\bar{x}=\infty \rightarrow \bar{y}=y_{P}, \\
x=\infty \rightarrow \frac{d y}{d x}=\frac{d y_{P}}{d x} .
\end{gathered}
$$

Considering the above dependences we obtain: from the first and second conditions:

$$
C=D=0 \text {. }
$$

The solution has a similar form (without $\ddot{A}$ i $B$ ):

$$
\begin{gathered}
y=e^{-\overline{\varphi_{1}} \bar{x}} \cdot\left(\bar{A} \cdot \sin \left(\overline{\varphi_{2}} \bar{x}\right)+\bar{B} \cdot \cos \left(\overline{\varphi_{2}} \bar{x}\right)\right)+ \\
-\begin{array}{c}
x^{2} \\
2 \cdot R_{0}
\end{array}-\frac{g}{k} .
\end{gathered}
$$

Considering the whole beam CBD with intervals $\mathrm{CB}$ and $\mathrm{BD}$, we have to find the following unknowns: $\mathrm{B}$ and $\mathrm{C}$ for the interval $\mathrm{CB} ; A$ and $B$ for the interval $\mathrm{BD}$.

Boundary conditions in butt joint for segments $\mathrm{CB}$ and $\mathrm{BD}$ are:

$$
\begin{gathered}
x=\frac{l}{2} ; x=0 \\
1^{0} y\left(\frac{l}{2}\right)=y(0) \text { and }\left.2^{0} \frac{d y}{d x}\right|_{x=\frac{l}{2}}=\left.\frac{d \bar{y}}{d \bar{x}}\right|_{x=0},
\end{gathered}
$$

$$
\left.\begin{array}{r}
3^{0} d^{2} y \\
d x^{2}
\end{array}\right|_{x=\frac{l}{2}}=\left.\frac{d^{2} \bar{y}}{d \bar{x}^{2}}\right|_{\bar{x}=0} \text { and }\left.\quad 4^{0} d^{3} y\right|_{x=\frac{l}{2}}=\left.\frac{d^{3} \bar{y}}{d x^{3}}\right|_{\bar{x}=0} \text {. }
$$

The contact condition [10] has to be taken into consideration as well:

$$
5^{0} y \frac{l}{2}=y_{p} \text { orazy } 0=y_{P} .
$$

From the first of the four conditions we obtained the system of four non-linear equations with four unknowns.

From the condition $5^{0}$ we have:

$$
\text { y0 } 0=y_{P} .
$$

The following equation is obtained:

$$
B=\frac{g}{k} .
$$

Substituting the dependences shown above, we obtained the system of non-linear equations:

$$
\begin{gathered}
\text { I } \begin{array}{c}
Q \\
2 \cdot H \cdot \beta
\end{array}{ }_{2}^{\beta \cdot l}+B \cdot \cos { }_{2}^{\beta \cdot l}+C+\frac{Q \cdot l}{4 \cdot H}-l^{2} \\
8 \cdot H
\end{gathered}
$$

$$
\text { IV } \begin{gathered}
Q \cdot \beta^{2} \cdot \cos \left(\begin{array}{c}
\beta \cdot l \\
2 \cdot H
\end{array}\right)+B \cdot \beta^{3} \cdot \sin \left(\begin{array}{c}
\beta \cdot l \\
2
\end{array}\right)+ \\
-A \cdot\left(3 \cdot \varphi_{1}^{2} \cdot \varphi_{2}-\varphi_{2}^{3}\right)=\frac{g \cdot\left(-\varphi_{1}^{3}+3 \cdot \varphi_{1} \cdot \varphi_{2}^{2}\right)}{k}
\end{gathered}
$$

$\frac{Q \cdot \beta^{2}}{2 \cdot H} \cdot \cos \frac{\beta \cdot l}{2}+B \cdot \beta^{3} \cdot \sin \frac{\beta \cdot l}{2}-A \cdot\left(3 \cdot \varphi_{1}^{2} \cdot \varphi_{2}-\varphi_{2}^{3}\right)=$

$$
g \cdot\left(-\varphi_{1}^{3}+3 \cdot \varphi_{1} \cdot \varphi_{2}^{2}\right)
$$

In this system we have the following unknowns: $B$, $C, l, A \rightarrow$ (for segment $\mathrm{BD}$ in place of $A$ ).

Analysing the obtained non-linear system (for example, using Newton's method or special computer program [7]), it is possible to obtain the diagram of track 
deflection $(11,17)$. Also diagram of external force $M$ can be obtained.

$M=\left(-A \cdot \sin (\beta \cdot x) \cdot \beta^{2}-B \cdot \cos (\beta \cdot x) \cdot \beta^{2}-\frac{g}{H}\right) \cdot E I$.

4. Stable equilibrium analysis of compressed and lifted rail, laid on initial curved subgrade under the influence of temperature

The profile of maintained railway is given in Fig $4 a$. It shows an approximate distribution of initial deflection of railway in vertical plane $[7,8]$.

a)

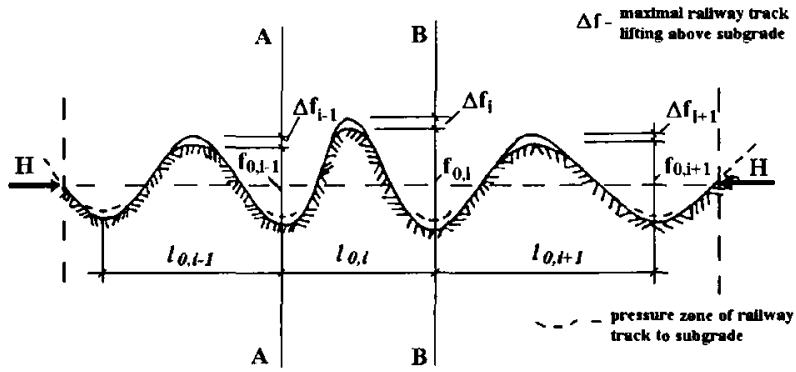

b)

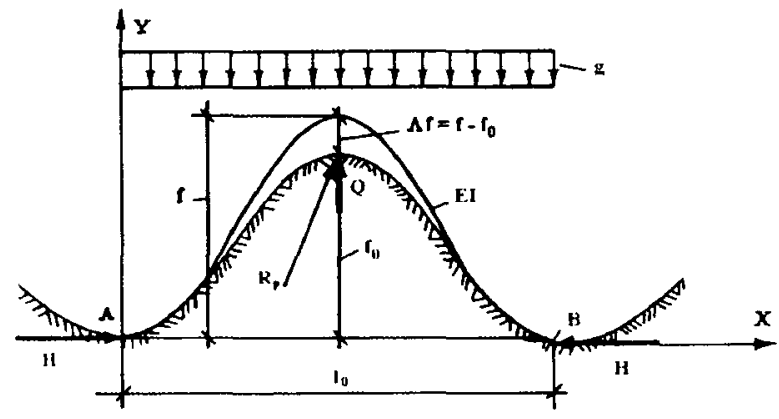

Fig 4. Schematic diagram: a) interval of the maintained railway, b) analytical diagram

The main problem is to determine an adequate analytical model suitable for the effects discussed above. While selecting the proper analytical scheme, we have to remember that our diagram was suitable for railway behaviour under real conditions. Also, we have to take into account all active forces applied to the system considered. Because of that the most approximate model was shown in Fig 4b [8].

\subsection{Analytical diagram}

We define the equilibrium state of initial deformed rail interval with the following properties (Fig 4b): ponderable beam $(\mathrm{g})$, bending stiffness in vertical plane $(E I)$, longitudinally compressed thermic force $(H)$, lifted by a vertical force $(Q)$, laid on local curved roadbed, at de- flection $(f)$ and wave length $(l)$. The influence of roadbed vertical flexibility on the bar deformed axis is neglected.

The considered local convex curve of roadbed is given as a function:

$$
y_{0}=\frac{f_{0}}{2} \cdot\left(1-\cos \left(\begin{array}{c}
2 \cdot \pi \cdot x \\
l_{0}
\end{array}\right)\right)
$$

The approximated form of rail axis deformed in the whole length contact loss has a similar form specified as a function:

$$
y=\frac{\Delta f}{2} \cdot\left(1-\cos \left(\begin{array}{c}
2 \cdot \pi \cdot x \\
l_{0}
\end{array}\right)\right),
$$

where $\Delta f$ is the height of movement of curved rail.

The state of considered configuration can be defined by the following equation (according to variation rule of LAGRANGE - minimum of potential energy) [9]:

$$
\delta(V-T)=0,
$$

where

$V$ - elastic energy of system $\left(V_{g}+V_{M}\right)$,

$V g$ - elastic energy due to weight of track,

$V_{M}$ - elastic energy due to bending moments,

$T$ - energy of external forces produced an effect on the system $\left(T_{H}+T_{Q}\right)$,

$T_{H}$ - energy due to compressed force of system,

$T_{Q}$ - energy due to lifted force of system [10].

Using data from Fig 4 and formulas for $V$ and $T$ (see above), it was obtained:

$$
\begin{gathered}
V=\frac{1}{\left(l_{0}\right)^{3}} \cdot \pi^{4} \cdot \Delta f^{2} \cdot E I+\frac{1}{2} \cdot g \cdot l_{0} \cdot \Delta f, \\
T=\frac{1}{4} \cdot H \cdot \pi^{2} \cdot \Delta f \cdot \stackrel{\left(2 \cdot f_{0}+\Delta f\right)}{l_{0}}+Q \cdot \Delta f .
\end{gathered}
$$

Using variation rule of LAGRANGE we obtain:

$$
\Delta f=\frac{f_{0}-\frac{g \cdot\left(l_{0}\right)^{2}}{\pi^{2} \cdot H}+\frac{2 \cdot Q \cdot l_{0}}{\pi^{2} \cdot H}}{\left(\frac{H_{K R}}{H}\right)-1},
$$

whereas

$$
H_{K R}=\frac{4 \cdot \pi^{2} \cdot E I}{\left(l_{0}\right)^{2}}
$$

Denote value of critical force $H$ for clampedclamped beam (Fig 4b).

Taking into consideration Fig $4 \mathrm{~b}$ and $\Delta f$ we obtain the dependence for axis railway deflection:

$$
f=\frac{f_{0}-f_{g}+f_{Q}}{1-\frac{H}{H_{K R}}}
$$


where

$f_{g}=\frac{1}{4} \cdot g \cdot \frac{\left(l_{0}\right)^{4}}{\left(\pi^{4} \cdot E J\right)}$ - the approximated rail deflection in the interval $l_{0}$ due to weight of track for clampedclamped beam,

$f_{Q}=\frac{1}{2} \cdot Q \cdot \frac{\left(l_{0}\right)^{3}}{\left(\pi^{4} \cdot E l\right)}$ - approximated rail deflection in the internal $l_{0}$ due to force $Q$ for clamped-clamped beam.

In the non-dimensional system the dependence (34) has the following form:

$$
f_{0 K}=\frac{\frac{f_{0}}{f_{0 K}}-\left(\frac{l_{0}}{l_{0 K}}\right)^{4}+\omega \cdot\left(\frac{\left(l_{0}\right)^{3}}{\left(l_{0 K}\right)^{4}}\right)}{1-\left(\frac{l_{0}}{l_{0 K}}\right)^{2}} .
$$

The three characteristic relationships from formula (35) are calculated by the following dependences:

$$
f_{0 K}=\frac{4 \cdot E I \cdot g}{H^{2}} ; \quad l_{0 K}=2 \cdot \pi \cdot \sqrt{\frac{E I}{H}} ; \quad \omega=\frac{2 \cdot Q}{g}
$$

\subsection{Minimum definition of the contact loss between rail and subgrade caused by lifted force}

Taking into account the dependences shown above, it is possible to define the minimum value of the lifted force $Q$. This force results in full loss of contact between rail and roadbed when track weight is insufficient.

For $\Delta f \leq 0$ (32) (effect of full contact between rail and subgrade), we have

$$
Q_{K R} \leq \frac{1}{2} \cdot\left(-f_{0} \cdot \pi^{2} \cdot H+g \cdot\left(l_{0}\right)^{2}\right) .
$$

\subsection{Definition of permissible convex curve radius on site}

From the relationship (32), it is possible to determine condition of rail proper behaviour when:

$$
R_{P} \geq 0,5 \cdot \frac{H}{g},
$$

where $R_{P}$ - convex curve radius on site calculated from the formula:

$$
R_{P}=\frac{1}{2} \cdot l_{0} \cdot \frac{\left(g \cdot l_{0}-2 \cdot Q\right)}{\left(f_{0} \cdot\left(\pi^{2} \cdot g\right)\right)} .
$$

Curve radius for rail is defined:

$$
R_{d}=0,5 \cdot \frac{m \cdot n \cdot H}{g}
$$

where

$m$ - coefficient considering the influence of braking forces caused by trains, $n$ - safety coefficient.

\subsection{Definition of admissible railway track lifting}

Values $\Delta f_{\max }$, when $l_{0}<l_{0 K}$ and $\Delta f_{\min }$, when $l_{0}>l_{0 K}$ have to be defined. They can be obtained from the following formulas:

$$
\begin{aligned}
\Delta f_{\max , \min }= & \frac{f_{0} \cdot\left(\frac{l_{0}}{l_{0 K}}\right)^{2}-f_{0 K} \cdot\left(\frac{l_{0}}{l_{0 K}}\right)^{4}}{1-\left(\frac{l_{0}}{l_{0 K}}\right)^{2}}+ \\
& \frac{\omega \cdot f_{0 K} \cdot \frac{\left(l_{0}\right)^{3}}{\left(l_{0 K}\right)^{4}}}{1-\left(\frac{l_{0}}{l_{0 K}}\right)^{2}}
\end{aligned}
$$

$\frac{l_{0}}{l_{0 K}} \quad$ is substituted as follows:

$$
\frac{l_{0}}{l_{0 K}}=\sqrt{1 \pm \sqrt{1-\frac{f_{0}}{f_{0 K}}}},
$$

whereas sign "-" denotes $\Delta f_{\max }$, and "+" denotes $\Delta f_{\min }$. Using the obtained relationship (41) and deflection value for lifted rail from the formulas $(22-25)$, it is possible to determine the diagram of admissible rail lifting - Fig 5.

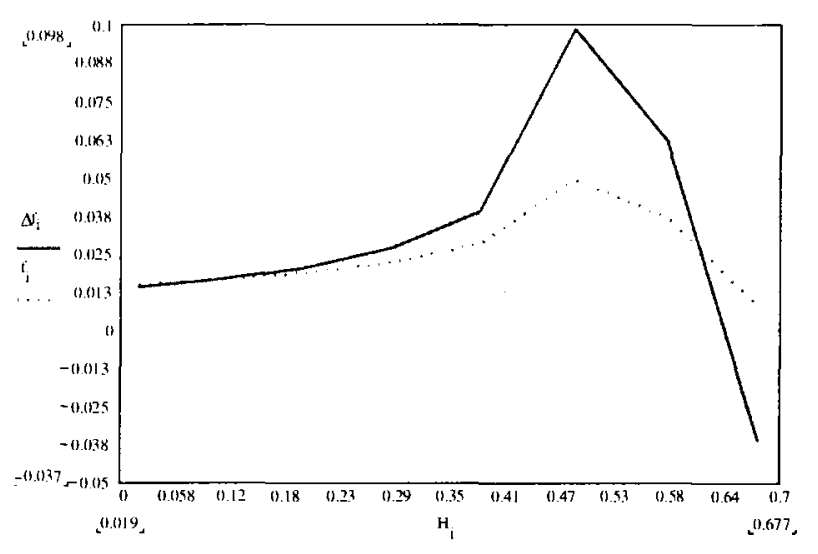

Fig 5. Diagram of admissible rail lifting

\section{Conclusions}

1. Non-linear equation system (22-25) was obtained. Influence of various conditions (for example, subgrade flexibility or its initial curve) is taken into account for the final form of deformed railway track axis. 
2. Performing calculations $(\mathrm{k} \rightarrow \infty)$ model of stiffed roadbed (non-flexible) was obtained $[7,11]$.

3. Using formula (26) it is possible to define the diagram of bending moments (stresses) on optional intersection of rail during its permissible movements.

4. When temperature is maximum $\left(\Delta t_{\max }=45^{\circ} \mathrm{C}\right)$, measurements of modulus of elasticity are impossible.

5. When the temperature increase is $\Delta t=20^{\circ} \mathrm{C}$ above the fastening temperature, rail movement can reach a value of even $8 \mathrm{~cm}$ at $f_{0}=2 \mathrm{~cm}$ and $l_{0} \approx 23 \mathrm{~m}$ (wooden sleepers).

6. Permissible convex curve radius for rail on wooden cross-beams tie is $R_{d}=467,962 \mathrm{~m}$. Also convex curve radius on site (39) has to satisfy dependence (38) extended at formula (40).

7. For rail movement on wooden sleepers, when VSS plate is used, it is possible to do safety measurements when the increase of temperature is $\Delta t_{\max }=28^{\circ} \mathrm{C}$ above the fastening temperature (Fig 5).

\section{References}

1. Hilling J., Lieberenz K., Mögel M. Long-term behaviour of bonded-fibre fabrics in railway line load-bearing systems. Der Eisenbahninginieur, Heft 4/99. Frankfurt-amMain, p. 44-49.

2. Kinnoek N., The White Paper on revitalising railways. Rail International, $28^{\text {th }}$ year, May 1997 , p. 2-6.

3. Korpanec I. Major Projects of Joint European Railway Research. Japan Railway \& Transport Rewiew, 1996, No 7, p. 16-21.

4. Neumann Z., Bednarek Wl. Variability of deformation used track way after roadbed modernisation. In: Proceedings of the VII International Conference "High-speed lines" (Zmiany odkształcalności eksploatowanego torowiska wzmocnionego podczas modernizacji podtorza. Materiały
VII Międzynarodowej Konferencji „Linie dla dużych prędkości"). Zylina, 1996, p. 81-86 (in Polish).

5. Szumierz W. Analysis of contact loss between track way and subgrade. Civil engineering archives (Analiza utraty kontaktu prostego toru bezstykowego $\mathrm{z}$ podłożem. Archiwum Inżynierii). Ladowej, Vol XIX, No 2, 1973 (in Polish).

6. Bednarek Wl. Problem of railway contact loss with track subgrade in vertical plane. In: Proceedings of X National Scientific and Technical Conference "Railways - 99" (Materiały X Krajowej Konferencji Naukowo-Technicznej „Drogi Kolejowe '99”). Spala, 13-15. Oct 1999, p. 315324 (in Polish)

7. Bednarek Wl. Influence of railway grade on stability of track way in vertical plane during investigations of roadbed with plate VSS. In: Proceedings of IX National Scientific and Technical Conference "Railways - 97" (Materiały IX Krajowej Konferencji Naukowo Technicznej „Drogi Kolejowe '97”). Cracow, 5-7 Nov 1997, p. 45-56 (in Polish).

8. Szumierz W. Influence of roughness on stability jointless track. Railway Review (Przegląd Kolejowy), Vol 5/93, p. 513 (in Polish).

9. Szumierz W. Stability of simple jointless track under temperature changes. Civil Engineering Archives (Archiwum Inżynierii Lądowej), Vol XVII, No 2, 1971 (in Polish).

10. Szumierz W. Problems of stability jointless track. Railway Review (Przegląd Kolejowy Drogowy), No 6, 1966, p. 118 (in Polish).

11. Bednarek Wl., Rychlewski J., Siewczynski B. Possibilities of using specific PC programmes - practical examples and employment in didactic. In: Proceedings of II National Conference of Slask Politechnic (II Ogólnopolska Konferencja Politechniki Śląskiej „Wspomaganie Komputerowe Nauczania Przedmiotów Komunikacyjnych i Geodezyjnych na Wydziałach Budownictwa Lądowego"). Gliwice, 19-20 Nov 1998, p. 191-196 (in Polish). 